\title{
The Slow Violence of Contemporary Policing
}

\section{Rory Kramer and Brianna Remster}

\author{
Department of Sociology and Criminology, Villanova University, Villanova, Pennsylvania \\ 19085, USA; email: rory.kramer@villanova.edu, brianna.remster@villanova.edu
}

\begin{abstract}
An estimated 60 million Americans encounter police annually and more than one million are threatened or subjected to police use of force during these encounters. Much research exists on the efficacy for crime control of the policing practices that produce those encounters, but outside of formal consequences such as incarceration, the criminology of police harms has been slower to emerge. In this review, we describe the slow violence that contemporary policing practices disproportionately inflict on people of color. These wide-ranging harms constitute cultural trauma, shaping health, well-being, academic performance, government participation, community membership, and physical space. As a result, routine policing practices help create and maintain the racial and class status quo. We close by considering the limits of popular reforms given those harms and urge researchers to take a broader approach by studying nonpolicing alternatives to public safety alongside crime control efficacy and incorporating more critical perspectives to build a more comprehensive assessment of modern policing practices.
\end{abstract}




\section{INTRODUCTION}

When Derek Chauvin knelt on George Floyd's neck in front of fellow officers and residents for nine minutes and twenty-nine seconds, killing Floyd over a counterfeit twenty-dollar bill, mass demonstrations erupted across the United States. These protests were the largest in American history-between 15 and 26 million participated - and the most diverse (Buchanan et al. 2020). Large-scale property damage and aggressive police responses accompanied these events, further intensifying calls to fundamentally rethink policing.

Much like the 1960s Civil Rights Movement caught social science largely flat-footed (McKee 1993), so too has the Black Lives Matter movement, especially the 2020 civil uprisings, even as classic studies recognize American policing as both highly problematic and formative in citizens' views of the state (Bittner 1970). Although research on the multifaceted impacts of contemporary policing practices on Black and Brown Americans grew in recent years, much of it emerged outside of mainstream criminology (for important exceptions, see Brunson 2007, Cobbina et al. 2019, McCarthy et al. 2020, Slocum \& Wiley 2018). That recent literature is the starting point for this review; we argue that the study of policing is best served by reconsidering policing efficacy and broadening its scope to include nonpolicing alternatives to public safety as well as taking note of the varied and far-reaching harms that institutional policing practices inflict.

Criminology has the expertise to help reshape policing and public safety programming, but our recent focus on policing efficacy in terms of crime rates or how well reforms reduce racial disparities has been limiting. As Goff (2021, p. 678) recently argued in light of research demonstrating the benefits of diversifying Chicago's police department, scholarship should ask "questions that align less with 'how can we fix this' and more with 'why are we doing this at all." Building on Goff, we summarize scholarship that is rethinking the guiding questions researchers ask about policing and police-civilian interactions and the methods and data used to study them. We urge scholars to consider the benefits and harms of policing concurrently, as well as the role of policing practices in maintaining state power and capital more broadly, to produce a more comprehensive assessment of modern policing. We primarily discuss American policing, but international studies demonstrate similarities in policing inequities, theorizations, and criminological blind spots across national borders (see González 2017, Sclofsky 2020 ).

The study of policing should center the "slow violence" (Nixon 2011, Ward 2015) that police impose on Black and Brown Americans as agents of the state. Slow violence is the "more attritional, dispersed, and hidden" racial and class-based harms inflicted by the state (Ward 2015, p. 300). It is often unseen, either by being mislabeled as unrelated to policing or unacknowledged because its victims are marginalized people. These harms often lie outside criminology's traditional focus on "the making of laws, the breaking of laws, and reacting to the breaking of laws" (Sutherland \& Cressey 1955, p. 3). Slow violence illuminates these harms by broadening our view of the role of police in society, arguing that the utility of policing practices extends beyond social control. In conjunction with other US institutions, the institution of policing helps form and sustain the status quo via the harms policing practices inflict on people of color. Thus, slow violence focuses on the racially disparate harms caused by policing over the intent of actors; although official policies can be consciously biased, race-neutral, or even aimed toward minimizing racial injustice, officers most frequently characterize their department policies, as 
well as their own actions, as race-neutral colorblindness (Welsh et al. 2021).

Some particularly egregious policing harms have become visible in recent years thanks to video recording technology. Yet those viral videos of police using physical violence represent a tiny fraction of the daily amount of force police use, and most incidents and survivors' names remain unknown to the public. In 2018 alone, police threatened or used nonfatal force on an estimated 530,800 Black and Brown Americans (Harrell \& Davis 2020). At the same time, most police encounters do not include force, but the frequency of those encounters among people of color has led Black parents to teach their children how to interact safely with police (Dow 2019, Gonzalez 2019). The average young Black man in New York City, for instance, was stopped 8.6 times during the height of stop-and-frisk ( $\mathrm{SD}=17.9)$, and $45 \%$ of them were stopped by police in the past year (Geller et al. 2014). Proactive policing practices, in combination with the US's punitive turn beginning in the second half of the twentieth century, resulted in the mass criminalization of Black Americans (Hinton \& Cook 2021); approximately 23.4\% of Black Americans have a felony record relative to $8.11 \%$ of Americans overall (Shannon et al. 2017). Slow violence highlights the consequences of such ubiquitous police contact, including routine police use of force.

Slow violence defines violence broadly in order to consider how contemporary policing practices harm not only the individual stopped but also their peers, families, and communities. Throughout this review, we thus differentiate between force as police use of physical violence and violence as the larger set of harms inflicted by policing practices. 1 This violence includes the elevated rates of psychological distress and physical ailments among individuals, families, and neighborhoods targeted by frequent and invasive stops, i.e., aggressive policing (Legewie \& Fagan 2019). Feelings of social exclusion and government disenfranchisement, but also increased activism, represent another consequence of the slow violence of policing. Policing practices also commit slow violence by structuring physical space and defining community membership. Police define who can be where and when and distinguish residents worthy of protection from residents to be criminalized.

Slow violence also exposes the economic benefits of systematically harming people of color. City budgets, for instance, rely on the fines generated by policing practices (Beckett \& Harris 2011, Fernandes et al. 2019, Harris 2016, Pres. Task Force 21st Century Polic. 2015). Policing practices also help create financial capital by facilitating gentrification in some neighborhoods (Beck 2020) and by reducing land values elsewhere via policies such as gang injunctions (Muñiz 2015, Owens et al. 2021). Policing not only consumes a large portion of municipal discretionary budgets but also provides opportunities for private and public actors to capitalize on racially discriminatory policing practices. Thus, police help maintain an economic system that relies on the social category of race to justify the exploitation of workers of color to generate capital, known as racial capitalism (Pulido 2017). These forms of everyday slow violence are rarely

\footnotetext{
${ }^{1}$ Force, as defined by most police departments and researchers, is any physical contact by officers, including pushing, grabbing, handcuffing, hitting, kicking, using chemical or pepper spray, using an electroshock weapon, or pointing a gun.
} 
considered, yet are integral to understanding the stakes of contemporary policing.

Slow violence also requires researchers to reckon with the past because these harms are rooted in "social and historical relationships" (Ward 2015, p. 300). Fassin (2013, p. 44), for instance, argues in his ethnography of policing in France that "[ $t]$ he work of the police cannot be understood...purely in the moment of their interaction with the public....It articulates relations of domination that extend beyond the individual actions of officers." Many argue that the US criminal justice system is a system of racialized social control (Harcourt 2001, Hinton \& Cook 2021, Muhammad 2010, Rios 2011, Wacquant 2009), but this perspective is largely absent from policing research. Although policing has evolved in the centuries since its origins in colonialism, slavery, and class warfare, racially unequal outcomes - even and especially under race-neutral policies - remain a consistent hallmark of the institution across generations (Harcourt 2001, Hinton \& Cook 2021, Owusu-Bempah 2017, Pres. Task Force 21st Century Polic. 2015). To fully assess police efficacy, the official function of police as providers of public safety must be considered in conjunction with the slow violence this institution committed historically and continues to commit today. Given the breadth and scope of these harms, centering slow violence in the study of policing is imperative to criminology's not being caught flat-footed in the future.

\section{POLICE EFFICACY AND ITS LIMITATIONS}

A robust body of research shows that increasing police presence decreases crime and is cost effective. Using data on 242 cities spanning 50 years, Chalfin \& McCrary (2018) show that a $10 \%$ increase in the size of a police force is associated with a $7 \%$ decrease in violent crime, a smaller decrease in property crime, and a 5\% drop in victimization costs. The authors conclude that most American cities are underpoliced, and, although not causal, these findings generally align with those from quasi-experimental research. A trio of natural experiments leveraging a national hiring grant change finds that increases in police funding led to declines in violent and property crime (Cook et al. 2017, Mello 2019, Weisburst 2019b). Another study using an instrumental variable approach, in fact, reveals that more policing in California led to less incarceration, providing further evidence of safety and financial benefits (Kaplan \& Chalfin 2019). Together, these studies indicate that policing is efficacious for crime control, as hiring more officers is less costly than the crime those officers prevent.

Yet there is no consideration of alternative public safety programs in those assessments. Instead of asking whether more police is better than fewer police, the question should be whether more policing is better than alternative public safety expenditures. Other public policy spending can also provide public safety benefits, such as greening vacant land (Branas et al. 2016) and supporting community-based organizations (Sharkey 2018, Sharkey et al. 2017). Given the record high levels of civil unrest concerning police, weighing alternative possibilities like these is pressing.

More broadly, scholarship must consider how high rates of police contact affects communities aside from crime. This call is not new; for at least half a century, theorists have argued that policing studies err in focusing on crime control as opposed to the broader function of police as a state institution (Bittner 1970, Garland 2001, Harcourt 2001, Neocleous 2000, Simon 2009). By failing to do so, the literature misses the slow violence committed by police (Ward 2015), 
ranging from enforcing Black codes-where Black Americans were policed for speaking to a White woman or being unemployed - to contemporary practices such as stop-and-frisk. Police practices have made and continue to make Black Americans hesitate to leave their homes (Floyd v. New York 2013, Ray 2017).

The impact of modern policing practices for Black and Brown Americans in everyday life is part of why civil unrest and protests have reached new heights of late, yet research on police efficacy remains focused on measuring police's impact on crime control and research on other outcomes of policing is disconnected from police efficacy research. This is not to argue that research on police efficacy in terms of crime or incarceration rates is invalid or should not continue. Rather, it is to contextualize it as only one piece of the puzzle of understanding the function and impact of police and urge a reconsideration of the outcomes considered when measuring policing effectiveness. Criminology must also ask, how do policing practices shape residents' lives?

We begin by outlining recent innovative research on racial discrimination in policing and whether or not it can be attributed to individual officers' personal biases, before turning to the slow violence policing inflicts. We first highlight how aggressive policing harms physical and mental health and creates cultural trauma for people of color and specifically how aggressive policing shapes childhood for youth of color who are often targets of such policing. Next, we shift to consider how the slow violence of policing is not just responsive to the structure and organization of society but also implicated in creating those demands and expectations. From here, we consider how police structure space and place, emphasizing how policing practices help define the community and how they help reorganize the modern city. We conclude by discussing how this unified literature might engage with current reform and funding debates by scrutinizing assumptions about how and why police have become such a large component of modern governance (Neocleous 2000, Simon 2009; Vitale 2017). Doing so reframes these debates and offers new questions for future research while working to end the slow violence of policing.

\section{THE EXTENT OF RACIAL DISPARITIES IN POLICE-CIVILIAN INTERACTIONS}

Interacting with police is now a commonplace experience-more than 61 million Americans interacted with police at least once in 2018, nearly half of which were contacts initiated by police officers (Harrell \& Davis 2020). Although most encounters with the police end without physical violence, police use force on civilians several thousand times a day across the country; an estimated 1.2 million Americans experienced or were threatened with force in 2018 (Harrell \& Davis 2020). Even a small racial disparity in the likelihood of experiencing police use of force is meaningful, and research indicates that the disparity is not small (Gelman et al. 2007, Harrell \& Davis 2020, Knox et al. 2020). In our own work, we estimate that had Black Americans been treated similarly to Whites when stopped, the NYPD would have used force in 61,000 fewer stops of Black civilians from 2007-2014 (Kramer \& Remster 2018).

A burgeoning body of research documents the challenges of discerning whether these racial disparities are due to discrimination, thanks to differences in benchmarking strategies, use-offorce definitions, and sampling strategies (see Geller et al. 2020, Neil \& Winship 2018, Smith et al. 2021). Because these issues are the focus of Neil \& Winship's (2018) review, we highlight innovative research that addresses those issues, which finds consistent evidence of racial 
disparities in policing in terms of both who is exposed to police interactions and, once engaged in an interaction, who is exposed to police use of force.

Scholars have addressed potential bias problems in estimating racial disparities by using methods such as the veil of darkness test instead of benchmarking (Taniguchi et al. 2017, Hannon et al. 2021) and by clearly defining police use of force in light of jurisdictional definition differences (Goff \& Rau 2020). Others have focused on differences in stop outcomes (e.g., arrest) for White and Black civilians, finding substantial racial disparities in the likelihood that an investigatory stop includes use of force (Levchak 2017). In our own work, we found this racial disparity to be particularly high for stops of younger individuals even when adjusting for stop outcomes that should depress the disparity (Kramer \& Remster 2018; see also Morrow et al. 2017).

Another advancement in assessing the extent of racial disparities in police use of force employs a sequential understanding to police-civilian interactions. Knox et al. (2020) argue that these interactions begin with police suspicion of a civilian, and if this suspicion is racializedspecifically if police see Black people as more suspicious than Whites (see Russell-Brown 2009) - then Black people are more likely to be stopped inaccurately than Whites. Consequently, studies making racial comparisons in police use of force that do not take that difference into account produce conservatively biased estimates of racial disparities; the authors' bias-correction method roughly quadrupled the observed disparity compared to prior studies (Knox et al. 2020). This work is consistent with research on stop-and-frisk finding that Whites have a higher hit rate (uncovering drugs or weapons) than Black civilians (Gelman et al. 2007). Because racially biased, ineffective, and/or inefficient metrics for determining suspicion were used to make those stops, simulations indicate that nearly $75 \%$ of investigatory stops in New York City could be skipped with no impact on the total number of weapons found during stops (Goel et al. 2016).

Perhaps the clearest causal evidence of racial discrimination in police use of force comes from Legewie's (2016) quasi-experimental study of pedestrian stops in New York City. By examining temporal patterns of police use of force during stops before and after fatal shootings of police, Legewie shows that stops of Black pedestrians were increasingly violent during the two weeks immediately after two officers were killed by Black suspects. However, after two officer deaths that were attributed to a White and a Latinx suspect, stops of White and Latinx suspects were no more violent than at other times.

Much of this research leverages court-ordered data from New York City during a period of particularly aggressive use of stop-and-frisk policing, although research from other cities and after similar court rulings against racial profiling reports similar racial disparities (Epp et al. 2014, Hannon et al. 2021, Taniguchi et al. 2017). As cities change police tactics and more agencies are publishing data (for example, New Jersey's new Use of Force Portal includes more than 500 agencies of varying sizes), research should look beyond the few select large cities that originally released data because of court rulings or extensive FOIA requests.

\section{POSSIBLE CAUSES OF DISPARITIES: BAD APPLES, PSYCHOLOGICAL BIAS, AND NETWORKS OF MISCONDUCT}

Other research tries to identify what makes some officers more likely to use force than others. A 
common argument is the individualistic bad apples theory: that a subset of particularly biased officers is responsible for racial disparities in policing experiences. For example, the racial disparity in speeding ticket outcomes among the Florida Highway Patrol was explained by the behavior of roughly $40 \%$ of patrol officers (Goncalves \& Mello 2021). Analyses of police misconduct in Chicago complicate support for bad apples though. In support, Rozema \& Schanzenbach (2019) finds that civilian allegations of police misconduct are strongly predictive of future allegations against those same officers, and subsequent city litigation payouts.

Moreover, replacing the top one percent of officers with misconduct accusations with "average" officers would save Chicago an estimated four to six million dollars in damages over five years, in addition to lowering the number of officers with a disproportionate number of allegations. With these findings, the authors argue that "only officers with abnormally high allegations" (Rozema \& Schanzenbach (2019, p. 257) should be subject to intervention, in part because of the nonlinear relationship between allegations and litigation. However, a simulation study that replaced the top $10 \%$ of Chicago officers with misconduct complaints with an "average" officer found that total use of force was only reduced by four to six percent (Chalfin \& Kaplan 2020). That finding suggests that use of force is far more systemic to the way policing is performed; rooting out bad actors is not enough.

Some of this bad apples conundrum between studies may be due to different outcomes - future misconduct allegations versus use of force-but other misconduct complaint studies offer some clarity. For one, misconduct complaints are likely underestimated. Leveraging a change in the protocol for making a formal complaint, $\mathrm{Ba}$ (2016) shows that Black civilians are less likely to complete the filing process than Whites. That difference might in part be attributable to differential access to knowledge regarding the potential success of misconduct complaints filed. Most officers' actions are found to be justified in misconduct complaint investigations (Dewan \& Kovaleski 2020) and given disproportionate rates of contact with police, that knowledge might contribute to people of color underreporting. Furthermore, complaints made by Black and Latinx civilians are less likely to be sustained than those made by Whites in Chicago (Faber \& Kalbfeld 2019, Headley et al. 2020). Taken together, police use of force appears not to be concentrated among a small portion of officers. Instead, civilians who are more likely to experience forceBlack and Brown residents - are less likely to report. Nonetheless, reform efforts to reduce the bad apples problem are popular.

A common remedy to bad apples concerns is to improve the racial diversity of police departments, which is based on the rationale that officers with shared experiences and better understandings of the communities they police should use less force, and much research supports it (Legewie \& Fagan 2016; but also see Smith \& Holmes 2014). However, such thinking refutes the premise that racial disparities are due to a select few biased officers. Instead, it implicitly recognizes and signifies White officers' racial biases, as White communities are not concerned that non-White officers will be more violent to them than White officers. Examining 911 dispatch calls in two cities, Hoekstra \& Sloan (2020) find no racial or ethnic differences in officers' gun use in White and racially mixed neighborhoods. Yet in predominantly Black and Latinx neighborhoods, White officers are five times as likely to use their guns on civilians than peer officers (Hoekstra \& Sloan 2020). Ba et al. (2021) leveraged daily officer patrol shifts to avoid measurement error that may have confounded earlier studies of officer diversity. Their results indicate that White male officers in Chicago make more stops and arrests and use force 
more frequently than their colleagues, especially in Black neighborhoods, and this sizable disparity is driven by White officers' higher enforcement of low-level, nonviolent offenses (Ba et al. 2021).

Where does such bias come from, and how does it work? Police officers are subject to the same cognitive risk factors for racial bias as anyone else. The belief that Blackness is linked to criminality, for example, or the cognitive misrepresentation of Black people as physically more intimidating or threatening might also be at play during encounters (Eberhardt et al. 2004). Perversely, fear of being accused of racial bias - a form of stereotype threat - may shape police behavior; fearing accusations of racism is associated with greater support for use of force among officers (Trinkner et al. 2019). Goff \& Rau (2020) argue that situational factors specific to routine police work, including stereotype threat, increase the likelihood of activating officers' racial bias.

The research summarized so far in this section focuses on individual officers, but network analyses reveal that police misconduct, as well as shootings by police, may travel across social networks. One study indicates that roughly half of officers accused of misconduct are tied to other officers with misconduct accusations (Wood et al. 2019). Similarly, officers in Chicago who have fired their firearms are network brokers (Zhao \& Papachristos 2020); they tie otherwise disconnected networks of officers together and other officers may emulate brokers' problematic behavior (Ouellet et al. 2019). For example, Derek Chauvin had 18 recorded misconduct complaints when he killed George Floyd, his partner Thou had six, and the two officers who initiated the stop were being trained by Chauvin. Likewise, police misconduct accusations in London show a networked spread among officers (Quispe-Torreblanca \& Stewart 2019).

Network analyses remind us that treating officers or incidents as isolated or bad apples is a methodological choice, one that does not accurately reflect the racialized context of policing (Owusu-Bempah 2017, Roussell et al. 2017). In sum, studies find stark racial inequalities in policing experiences. As the rest of our review demonstrates, scholarship on policing that engages with social scientific understandings of structural racism, racial capitalism, and/or class inequality offers alternatives to the methodological individualism in the above studies. We next turn to research on the health consequences from racially disparate police encounters.

\section{POLICE AND HEALTH OUTCOMES}

Ruth Wilson Gilmore (2007, p. 28) defines racism as "the state-sanctioned or extralegal production and exploitation of group-differentiated vulnerability to premature death." Racial disparities in police killings are the most direct potential form of racism. The lack of national data on deaths caused by police, which quickly became a social scientific cliché, limits our ability to quantify the extent of this racial vulnerability. Crowd-sourced data help fill this void, generally finding ample evidence of systemic racism in lethal force committed by the state. Using the journalist-led Fatal Encounters database to calculate the race- and gender-specific risks, Edwards et al. (2019) estimate that roughly 1 in 1,000 Black men will be killed by police at the current rate, a risk that is nearly two-and-a-half times greater than that of non-Hispanic White men (Native American and White Latinos fall in between those two poles, whereas Asian and 
Pacific Islanders are less likely than White men to die from that cause). Gender is largely protective, with women experiencing a lower risk than men, but the racial pattern persists, with Black women at a higher risk than other women. Wrigley-Field (2020) builds on those estimates to quantify the average number of years that police killings shorten a person's life expectancy. Her findings reaffirm the same general pattern, but because White men are older on average when killed by police, the typical Black victim loses more years than a White victim. For every 100,000 Black residents, 5,696 years of life are lost to police encounters, of which 3,772 are directly attributable to police use of force (also see Bui et al. 2018).

Differential exposure to premature death is not always so direct though, thus public health scholars expanded Wilson-Gilmore's insight to argue that all police violence is a public health crisis of structural racism (Alang et al. 2017, Am. Public Health Assoc. 2018, Krieger 2015). Our past research and others' find that Black civilians are indeed at an elevated risk of exposure to nonlethal use of force during investigatory stops relative to Whites (Levchak 2017, Kramer \& Remster 2018) but no work to date exists on the potential physical health consequences for survivors of such violence. We hope this review encourages future research to focus on this, but an emerging body of work investigates how frequent, invasive police encounters shape community health as well as the mental well-being of individuals subject to those encounters. Continuing to draw on public health perspectives, such work conceptualizes the impact of experiencing or witnessing police violence as potential sources of racial health inequities (Alang et al. 2017). These include adverse physiological responses and stress, the impact of state and public justifications for police actions, and the systematic disempowerment of vulnerable groups.

In their foundational piece, Geller et al. (2014) assessed the mental health of young men in New York City. Police contact, repeated contact, and the intrusiveness and perceived unfairness of that contact are all associated with heightened anxiety and other trauma symptoms. Sewell \& Jefferson (2016) argue that exposure to aggressive policing shapes community health net of the impact on stopped individuals themselves. Living in neighborhoods with high rates of police use of force in New York is associated with poor self-rated health and increased risk of adverse health conditions like diabetes and high blood pressure, or what Sewell (2017) calls the "illness association of police violence." Concerning community mental health, Sewell et al. (2016) found that only men report higher rates of psychological distress in areas with increased police encounters.

Police violence is also associated with depression, psychological distress, and suicidal ideation in surveys of major cities (DeVylder et al. 2017, Geller et al. 2014). In a survey of medical clinic users in South and West Chicago, Smith et al. (2019) find that exposure to police use of force is associated with hypervigilance - the feeling of constantly having be on guard for danger - and this association is stronger for police violence than for other forms of violence. Hypervigilance is not unique to survivors of physical harm though; respondents who felt physically unsafe during a stop exhibit higher rates of hypervigilance relative to stopped respondents with no such fears, and hypervigilance is associated with higher blood pressure. Furthermore, residents of communities with high police violence also display higher levels of hypervigilance, with scores well above those typically associated with a posttraumatic stress disorder diagnosis, than communities with less police violence. 
Although the above research lacks causal evidence, these forms of slow violence showcase how policing is a source of cultural trauma for people of color (Onwuachi-Willig 2016). Alexander et al. $(2004$, p. 1) define cultural trauma as "when members of a collective feel they have been subjected to a horrendous event that leaves indelible marks upon their group consciousness, marking their memories forever and changing their future in fundamental and irrevocable ways." Traditionally, theories of cultural trauma focus on disruptions to daily life, such as a bombing, but Onwuachi-Willig (2016, p. 352) argues that cultural trauma also emerges "when common inequities in society repeat themselves... and more so, when such inequities are reaffirmed by public or official government entities." Police and quasi-police killings and subsequent nonprosecutions or acquittals are routinized harms producing racialized cultural trauma in the United States today (Onwuachi-Willig 2016). Frequent, invasive police encounters may create indelible marks on communities, especially Black communities given the state's historical mistreatment of Black Americans. The cultural trauma aggressive policing inflicts is especially relevant to considering youth of color's experiences with police, which we turn to next.

\section{POLICE IMPACT ON YOUTH}

Given the short, youthful nature of most criminal careers, much of the research on police contact examines the intersection of policing, race, and youth. Both qualitative and quantitative studies find that Black and Latinx youth are targeted by police from a young age (Rios 2011, Rios \& Vigil 2017). In our analyses of New York City, there were more instances of police use of force against Black teenagers than instances against Whites of all ages combined (Kramer et al. 2017). This targeting of Black youth is complicated by the adultification of Black youth, and research showing that holding racial stereotypes predicts racial disparities in police use of force against youth (Goff et al. 2014).

Aggressive policing specifically traumatizes Black youth as witnesses and survivors of police violence. For example, Baltimore youth describe dying at the hands of the police as a major childhood fear (Smith Lee \& Robinson 2019). Awareness of police violence also shapes Black parenting strategies and leads Black people to avoid behaviors that might draw police attention (Dow 2019, Ray 2017). Intersectional work notes that the emphasis on protecting Black boys marginalizes Black girls, who are seen as collateral to police violence (Gonzalez 2019). To protect themselves from criminalization, Black boys assert hegemonic masculinity by exaggerating romantic involvement with girls in public, which in turn heightens Black girls' risk of experiencing police force (Remster et al. 2019, Stuart \& Benezra 2018).

Community violence in general has a lasting effect on student performance and mental health (Sharkey 2018, Sharkey et al. 2014), but police violence is particularly traumatizing for kids of color. Using local variation in geographic distance to a killing by police, Ang (2020) shows that living in an area where police killed a Black or Latinx person has a larger marginal effect on GPA and absenteeism for Black and Latinx students than homicides that do not involve a police officer, whereas police killings of White people have no impact on local student performance. Black and Latinx students also report emotional disturbances that linger for months afterward (Ang 2020).

Police killings are relatively rare events, and most Black and Latinx youth do not live near those 
shootings. However, routinized aggressive policing is also negatively associated with youth outcomes (Legewie \& Fagan 2019). Using Fragile Families data, scholars find that both direct and vicarious exposure to police contact that did not end in arrest are associated with worse mental health and academic achievement (Gottlieb \& Wilson 2019). Exposure to aggressive policing is also an early form of legal socialization, and such experiences are associated with legal cynicism among teens (Geller \& Fagan 2019). Crucially, youth's views of police-initiated encounters rely on not only their direct experience with police contact but also the cultural frames through which they interpret police behavior (Slocum \& Wiley 2018).

Leveraging local variation in changes to stop-and-frisk rates, scholars show that students from neighborhoods subjected to an increase in stop-and-frisk have reduced test scores, net of local crime rates (Legewie \& Fagan 2019). This effect is primarily driven by Black boys who are disproportionately targeted for stops. Similarly, by assessing changes in stop-and-frisk policing due to the movement of local commanders, scholars show these encounters have a negative causal effect on high school graduation, college enrollment, and college persistence rates for Black and Latinx students (Bacher-Hicks \& de la Campa 2020). In contrast, White and Asian students, who are typically not targeted for police stops, reaped positive benefits; an increase in stop-and-frisk increased White and Asian students' academic success and safety (Bacher-Hicks \& de la Campa 2020).

Police also enact slow violence inside schools. Here, research indicates that policing is a hammer in search of a nail, and many argue that the increased police presence in schools in the form of school resource officers fuels the school-to-prison pipeline. Research utilizing variation in the introduction of school resource officers reveals that increasing police presence in schools yields mixed results in terms of safety but consistently increases the use of both exclusionary discipline - suspensions and expulsions - and criminal complaints against students, especially for low-level offenses (Gottfredson, et al. 2020, Owens 2017, Sorensen et al. 2020).

Furthermore, increasing police presence disproportionately increased low-level discipline for Black students in Texas and decreased graduation and college attendance rates (Weisburst 2019a). Concerning safety, on the one hand, Gottfredson et al. (2020) find no benefit to adding school resource officers in a matched sample comparison of schools that received federal funding to do so versus those that did not. On the other hand, an analysis of the rollout in North Carolina middle schools suggests that school resources officers do decrease violence in schools but at the cost of increased juvenile justice referrals for misdemeanor offenses (Sorensen et al. 2020).

School resources officers might provide some safety benefits for students, yet safety and policing concern youth as much, if not more, off school property (Shedd 2015). For instance, traveling to and from school often places students at risk of criminal and/or police victimization. Here, research shows that non-police-based approaches are particularly effective. A recent evaluation of the Safe Passages program in Chicago, which funds adult "guardians" for defined routes to and from schools and parks, shows that Safe Passage locations saw reduced violent crime, reduced absenteeism, and no evidence of crime spillover elsewhere (McMillen et al. 2019). Similarly, youth summer employment programs reduce criminal arraignments, especially among low-income youth of color, and this effect lasted for at least 17 months (Modestino 2019). As police contact is commonplace for so many, we next turn to consider how that routinized contact 
affects concepts of community, the state, and citizenship.

\section{POLICING AS A MEANING-MAKING INSTITUTION}

The combination of under- and overpolicing is a reality of modern policing; police fail to provide public safety for poor and working-class communities — especially those of color - while heavily surveilling those same communities. As such, police shape how society views individuals and communities; some people are valued less than others and some communities are less safe than others (Neocleous 2000, Samara 2010). In this section, we consider police as a "meaningmaking" structure of society (Bell 2019, 2020a) particularly by influencing individuals' and communities' sense of their social status and governance.

In a recent overview and call for work on how police affect citizenship, Soss \& Weaver (2017) illustrate how police are more than enforcers of long-standing racialized social control; police actively engage in race-making. As members of the dominant race, or working on behalf of the dominant race, police label and relegate large numbers of Americans into passive members of the racialized "other." In an innovative follow-up work - the Portals Project-Weaver et al. (2019) find that across cities, the human targets of aggressive policing are neither ignorant nor neutral concerning the purpose of these encounters. In other words, this meaning-making function of policing is central to understanding community tensions.

Because police are often the primary and sometimes only arm of government with which individuals in distressed communities interact, police are central to how citizens make meaning of their relationship to the government. Aggressive policing contributes to a distorted view of the responsiveness of government (Prowse et al. 2020). When aggressive policing is paired with an otherwise unresponsive government, frustrations stemming from police interactions expand to encompass a broader sense of government disenfranchisement (see Boyles 2015 for an ethnography of this in a suburban setting). This meaning-making of government as nonresponsive and simultaneously antagonistic to certain people is an especially insidious form of slow violence.

That aggressive policing shapes attitudes and participation in government, especially for communities of color, reveals the far-reaching consequences of policing. Recent work complicates this though; McCarthy et al. (2020, p. 530) find that legal cynicism, often caused by negative police encounters, is "not necessarily a neighborhood deficit, but may be productive in ways that benefit communities," insofar as it is related to increased reporting of police misconduct. This finding resonates with work documenting that both direct and vicarious experiences of police injustice can lead to greater community engagement (Cobbina et al. 2019). Instead of withdrawing, Rios (2011) shows how aggressive policing in Oakland spurs some Latino and Black boys to partake in racial justice activism, a finding our work confirms nationally (Remster \& Kramer 2018).

In sum, research indicates that the slow violence of policing produces alienation, cynicism, and activism. These findings are not necessarily at odds-legal cynicism may activate political involvement and demands for different policing strategies, but when those demands routinely go unmet, legal cynicism expands beyond the institution of policing into a wider disillusionment 
with governance and a sense of exclusion from society. In line with this formulation, Campeau et al. (2020, p. 3) report that residents of distressed neighborhoods view their arrest cynically but still yearn for "social recognition" and that "the promise of legality... acts as a resource for inclusion in the polity." Survivors of aggressive policing want both the material protection that they deserve from the state and the state's social recognition as full citizens with whom the state must engage and debate.

Recognizing that residents of communities of color have multiple, often conflicting views of police also helps resolve the seeming paradox of an individual who has been treated poorly by police relying on police and wanting more police (Campeau et al. 2020). Others claim there is no paradox given that police are the only aspect of the state that heavily policed communities experience; the state replies to a variety of community requests with only additional policing resources (Lerman \& Weaver 2014; Vitale 2017). Indeed, Black Americans often request more social safety net funding as well as police but generally only receive funding for police (Forman 2017). That reality has likely shaped, or at least reinforced, Black people's views of police as the solution and obscured alternatives. Demands for state support become requests for more police, not because police are the ideal intervention but because police are the visible and conceivable intervention.

Instead of debating whether or not this is a paradox, Bell (2019) argues instead that individual and community views of police are fluid; new experiences and/or needs continually shift views of police. Furthermore, many of Bell's (2020b, p. 928) respondents understood police as "operat[ing] at both an idealized aspirational level and a nonideal experiential level...even for black parents who have direct experiences with the police." Therefore "we might think of police protection as one component of the American dream, a chimera that people cling to even when doing so seems irrational..." (Bell 2020b, p. 950). Powell \& Phelps (2019) provide an example of such complexity in their study of Black women. Although Black women often require police, their gendered racial vulnerability creates "dual frustration," as police routinely fail Black women as crime victims and criminalize Black women and their loved ones. Ritchie (2017) argues these dual frustrations are formative in Black women's legal socialization, which in segregated and high-poverty Black neighborhoods often equates with attitudes toward governance more broadly (Soss \& Weaver 2017).

Examining how this marginalization process works in Latin America, González (2017) argues that police create a stratified form of citizenship. Although the United States has more capacity to provide public safety, its unequal distribution of safety reflects policing in Latin America. This stratification may "generate a negative feedback loop that fundamentally structures the practical manifestation of democratic citizenship" (González 2017, p. 495). This negative feedback loop exists outside of the Americas as well. For example, Koch (2017) finds that residents of a council estate (public housing) in England appropriate the police themselves as a mechanism to maintain everyday social relations instead of other more relevant and less punitive governmental agencies because those agencies fail to provide needed services, whereas police actually show up.

Another vein of research indicates that aggressive policing alienates residents from utilizing other institutions, possibly facilitating the overreliance on police that Koch (2017) documents. Brayne (2014) finds evidence of surveillance avoidance, where police encounters are negatively 
associated with involvement in a variety of different institutions, including banking, the labor force, and healthcare. This work also highlights the infiltration of police and/or police perspectives into other institutions and how collaborations between police and outwardly disparate institutions inflict slow violence. For example, combining ethnographic and emergency room admission data, Lara-Millán (2014) shows how the presence of police in emergency rooms leads to rushed, poorer quality service for patients - unless those patients were brought to the hospital by police (also see Seim 2020 on interactions between police and ambulance crews). Meanwhile, other individuals avoid seeking medical care when they need it because of police presence or access to this setting (Brayne 2014).

In sum, frequent, invasive policing may have lasting ramifications for one's relationship to the state, particularly when police disproportionately target people and communities of color and neglect to protect those same people and places from crime. Put differently, more formalized, repressive forms of social control such as arrest or incarceration are not necessary to reshape an individual's or community's value. Future research should explore how policing shapes how targeted individuals and communities interpret their relationship to the state and other formal institutions as well as how formal institutions use policing to shape their interactions with individuals and communities. This is not the only way police influence communities though; policing also structures communities in place and space, which is termed "segregation policing" by Bell (2019). We turn to these forms of slow violence next.

\section{POLICING AS ORGANIZING PEOPLE AND PLACE}

Organizational sociology provides insights into how racism permeates policing (TomaskovicDevey et al. 2004, Warren et al. 2006). Policing is not alone in this respect. In fact, Ray (2019) argues that all organizations are racialized. In this section, we consider how police organizational practice dynamics - including popular reform proposals - not only produce racial disparities in police encounters but also organize and define communities and spaces. By demarcating both who is safe and who is not and where is safe and where is not, police fortify state power and profit.

Beyond space, police racialize communities in several ways. Based on fellowship, the concept of community is intended to be inclusionary and to empower residents. Yet the very act of defining a community - determining who is and is not included by setting geographic boundaries or other criteria as well as who can speak for that entity - is political. Communities often affirm the disproportionate power of select individuals who fit the notion of a good citizen (Levine 2017), and that notion is shaped by who police deem community members. This function of police is especially striking in Sao Paolo, Brazil, because residents' racial status is often ambiguous and the city declares itself "raceless." In practice though, Alves (2018) shows how the concept of community is anti-Black, as police use brutal violence against residents they judge as Black but protect community members, i.e., Whites. Police terror and violence are a "constitutive/productive dimension of the city... [via] the gendered and racialized politics of security" (Alves 2018, p. 4). Based on her study of Argentina, Seri (2012, p. xi) contends that "police governance may help to carve out internal spaces of exclusion" and terms this police function "seguridad" to emphasize how police promote a brand of politics that merges one's sense of safety with the state's interest in security. Similar logics of police producing a racialized 
sense of (in)security in the city resonate around the globe, from Los Angeles gang injunctions (Muñiz 2015) to privatized policing of urban spaces in South Africa (Samara 2010). That this function of police exists across localities and countries is no surprise to international scholars, who note that regardless of whether a nation explicitly intends to export police practices elsewhere, slow violence practices diffuse across borders (Fassin 2013, González 2017, Sclofsky 2020).

Contrary to that body of work, community policing remains a popular reform to unite residents that have been historically excluded by police with residents typically deemed worthy of community membership and police. In support, studies consistently find that community policing practices improve residents' views of police (Natl. Acad. Sci. Eng. Med. 2018). However, recent studies considering the harms of slow violence reveal a more complicated portrait of community policing. Studying its implementation in Los Angeles, Roussell \& Gascón (2014, Gascón \& Roussell 2019) conclude that community policing does less to reshape policing than it does to legitimize the police-led definition of community; echoing international work, police delineate the community as residents in need of protection and the "anticommunity" as the individuals whose existence threatens the community. Roussell $(2015$, p. 821) argues that constructing the anticommunity also shapes space. For example, Gascón \& Roussell (2019) show that the police racialize residents by holding separate Black and Latinx community meetings, hand-picking leaders for each group, and rejecting residents who might challenge their authority. This aspect of community policing is reminiscent of political gerrymandering, where politicians pick their constituents instead of constituents picking politicians. Similarly, community policing allows police to define their constituency and reinforce their power rather than having to respond to communal complaints. Conversational analysis documents this process in action, revealing the common scripts police use during community meetings to avoid critique and maintain authority over the priorities of attendees (Cheng 2020).

Rios and colleagues (2020) go further and argue community policing resembles and reinforces the fear-based policing it is intended to resolve; it compliments rather than replaces physically aggressive policing practices. During their ride-alongs with officers, they found that police use tactics intended to improve community perceptions of fairness - procedural justice - in conjunction with more aggressive, punitive ones like invasive stop-and-frisks. Although these approaches appear at odds, the authors maintain that using both is strategic. By fostering trust with some residents while brutalizing others, police shift the blame for their own aggression to stopped individuals. Procedural justice "become[s] folded into the exercise of submission to police authority" and community policing becomes a form of "information gathering," with residents informing on their so-called hostile neighbors (Rios et al. 2020, p. 71). This newer form of slow violence illustrates how state harms evolve over time, and one way this happens is by exploiting reforms to earlier forms of slow violence. Here, police win some residents over by acknowledging the community division they created while continuing to perpetuate that divide with different tactics. Using the information generated from such tactics represents perhaps the most cutting-edge police harm.

Proactive policing as information gathering is central to the rise of big data policing. Scholarship shows how police in Los Angeles define and proactively create a community and anticommunity more regularly, more mundanely, and more powerfully than via engaging or withholding 
community policing practices (Brayne 2020, Ferguson 2019). In Brayne's (2020, p. 121) words, "Police-civilian interactions are no longer one-off, in-person encounters. Much of contemporary policing is programmatic, suspicionless, cumulative, probabilistic, and technologically mediated. It involves not only police-civilian interactions, but also police-dataset interactions, in which the data are often collected by nonpolice actors, before legal protections guarding against police overreach come into play." Police choose which civilians to pursue, and the resulting encounters become data collection. That data then affects the likelihood of future encounters. By marking individuals or areas as high risk or suspicious, police perceptions directly shape criminal justice system involvement (see also Muñiz 2015). Moreover, police reaffirm and reinforce labels assigned by non-law-enforcement personnel to individuals and spaces by using data from other institutions. Police are often characterized as reactive agents in the context of big data, using the tools they have been provided, but police also influence how those tools are used and against whom. This is poignantly demonstrated in Brayne's (2020) work, where LAPD officers refused to activate the GPS monitors on their cars because they did not want to be surveilled on the job, despite their agency's use of automatic license plate scanning to surveil civilians.

Although typically responsive to big data definitions of local geography, a small but growing body of work argues that another way police commit slow violence is by shaping that geography (Herbert 1997). Police racialize and provide place-consolidation (Gordon 2020) via their sheer visibility, their interactions with civilians, and by setting spatial boundaries with precincts. This function of modern policing works in tandem with the state's creation of public safety and safety deficits to promote private capital interests (Neocleous 2000, Simon 2009). Several studies show how police use race and class to achieve that perpetual insecurity (Fischer 2019, Muñiz 2015, Stuart 2011). In her study of Boston's redevelopment in the 1960s and 1970s, including the creation of an Adult Entertainment District, Fischer (2019, p. 10) argues that "aggressive, racially charged moral policing was central to the implementation of a new urban economic order organized around private investment capital, White homeownership and downtown commercial entertainment." Roughly a decade later, across the country in Los Angeles, Muñiz (2015) contends that gang injunctions are efforts to contain people of color, protect real estate values outside of injunction zones, and promote gentrification in and around injunction zones. Other work finds that injunctions are not only ineffective in reducing crime in injuncted zones but also decrease home values in those areas (Owens et al. 2021).

Police contribute to gentrification processes by other means too. Beck (2020) finds that police increase proactive tactics as neighborhood real estate value increases in New York. In other words, police help clean up a neighborhood to make it amenable to middle-class residents. As the middle-class population grows in a gentrifying neighborhood, calls to police for service increase but arrests and proactive stops do not (Beck 2020). Police may also adjust when and how they use force in gentrifying neighborhoods. Lautenschlager \& Omori (2019) show that police use force less frequently as neighborhood racial and ethnic diversity increases, but they use more severe force in those instances. Thus, gentrification leads to a decline in routine use of force and ramps up more severe force, perhaps via out-of-place policing. Police may react more harshly against individuals they perceive as out of place in gentrifying neighborhoods, despite using force less frequently overall. Together, these studies lay the groundwork for future research examining at how the slow violence of policing is part of the process of demographic change and financialization of land values. 
Police also contribute to space making and gentrification via complaint-oriented policing, development-driven policing, and segregation policing, which share common threads. In San Francisco, police reinforce residents' definitions of problematic behavior, as Herring (2019) finds that most police interactions are initiated at residents' requests for intervention, i.e., complaint oriented. Drawing on more than four million requests for service and accompanying police on these calls, Herring shows that police spend the vast majority of their shifts responding to calls, and in San Francisco most of those calls concern homelessness. Police express frustration at having to perpetually enforce city statutes that criminalize poverty; they see citation writing as a hassle, not to mention ineffective at addressing homelessness. Furthermore, residentinitiated citations invariably lead to future calls for service, resulting in a seemingly endless game of whack-a-mole for police. Although seemingly unpopular on the ground, complaintoriented policing combined with the criminalization of poverty is a part of what Beck (2020) calls development-driven policing. By routinely shuffling visibly homeless people around, police may facilitate capital investment in an area. Examining expenditures in 171 cities, Beck \& Goldstein (2018) demonstrate that the growing reliance on real estate property values and/or welfare retrenchment is associated with increased police expenditures, despite the general decline of victimization in the 1990s and 2000s.

Policing practices oriented toward real estate values, the criminalization of poverty, and servicing gentrifying middle-class residents aligns with Bell's (2020a) segregation policing. Here, Bell reignites and enhances scholarship on the police as protectors of both racial geographic divisions and private capital (see also Anderson 2016, Kramer 2017). These deeply intertwined goals are often achieved via the same practices. Segregation policing also extends the analysis of police as a racializing organization from urban settings into the suburbs. Examining how suburban annexation changed policing for a formerly unincorporated black community, Boyles (2015) charts how the promise of enhanced community services such as policing helped convince Black residents to support the change. Post annexation, the new municipality's policing practices reinforced Black residents' social and spatial isolation instead of integrating them into the wealthier, Whiter area. Related literature highlights policing and the fines they produce as a major fundraising mechanism for local municipalities (Beckett \& Harris 2011, Fernandes et al. 2019, Harris 2016, Pres. Task Force 21st Century Polic. 2015). Given the resurgence of city living among White middle- and upper-class Americans and continued debate within urban scholarship about how that increase is associated with gentrification, displacement, and other urban inequalities, further research on how police and police reforms are part of the defining and redefining of space and the community in the modern city and suburb is an important avenue for future work.

\section{SLOW VIOLENCE: RECONSIDERING THE ROLE OF POLICE FOR FUTURE REFORM AND RESEARCH}

Since the first wave of national Black Lives Matter protests six years ago, reforming policing became a major topic of local and national politics. Critics of reform note the persistence of these issues across generations, arguing that quotes from the President's Task Force on 21st Century Policing could be replaced verbatim with text from the 1967 Kerner Commission, and the same applies to the Kerner Commission with text from the 1931 Wickersham Commission (Kaba 2020). Another common critique is that reform does not necessarily produce improvement. 
Broadly speaking, American policing has been in the continual process of reform since it began. Body camera programs are a recent expensive example. Reviews indicate mixed findings, but body cameras appear largely ineffective in reducing police use of force or citizen complaints (Lum et al. 2019, 2020). Worse, police became more likely to use force after the introduction of Tasers; police were less cautious because Tasers were presumed to be nonlethal (Ba \& Grogger 2019, Sierra-Arévalo 2019). The lack of benefits from technology-based reforms is unsurprising through the lens of slow violence, as the root causes of police violence-institutional policies and practices that maintain the status quo-remain unchanged.

Calls for data collection and data-driven policing are another focus of reform efforts. As scholars, we support greater data collection and transparency yet heed Brayne's (2020, p. 29) caution concerning the appeal of mechanical objectivity:

In contrast to an individual's personal account of an emotionally fraught event such as a police-involved shooting, data are ostensibly stripped of subjective interpretation, and presented as objective measures...data are, no matter how they are presented, social products of social contexts... Thus, there is reason to be wary when data-driven policing is offered as the antidote to racially discriminatory practices in police departments across the country.

Concerns about claims of objectivity are not new; the United States first began collecting crime data by race to justify and inflict harms on Black Americans (Muhammad 2010, Ward 2015). However, new data collection techniques expand the scope of this tool and, in conjunction with mechanical objectivity misconceptions, may be especially harmful. For instance, although immigration enforcement is beyond the scope of this review, data-sharing and big data analyses are essential to the growth in immigration enforcement by local jurisdictions (Armenta 2017).

Efforts to retrain police and rewrite policies to improve procedural justice are among the most popular reforms. These efforts are rooted in research showing that an unfair police encounter has lasting consequences and that improving perceptions of police fairness is beneficial; doing so may reduce police use of force, reduce complaints filed by civilians, and improve residents' overall views of police (Meares et al. 2015; Natl. Acad. Sci. Eng. Med. 2018; Pres. Task Force 21st Century Polic. 2015; Tyler 2003, 2004). Recent evaluations of procedural justice style reforms find substantive effects (but see Nagin \& Telep 2017, 2020 for a critique). For example, a randomized control trial of a community policing program promoting procedural fairness during brief, door-to-door encounters in New Haven, Connecticut, improved civilian views of police legitimacy, an uptick sustained for three weeks following encounters (Peyton et al. 2019). In Chicago, officers who completed procedural justice training used force less frequently than officers who had not, but the training had no impact on civilian complaints (Wood et al. 2021).

However, theorizing policing as slow violence demonstrates that policing is not only consequential when civilians feel they were treated unfairly during a police encounter. Instead, routinized aggressive policing defines community, citizenship, and space for Black and Brown Americans. It shapes physical and mental health as well as academic performance. In this light, procedural justice and community policing reforms more broadly are limited by focusing on how and what police can do to improve the quality of frequent, invasive encounters. As Rios et al. (2020, p. 72) note, such reforms may only act as a "velvet glove sheathing an iron fist." In 
addition to reform objectives, the focus of studies determining the costs and benefits of reforms should carefully considered; for instance, evidence of reduced complaints may be driven by an increase in officers explaining their justifications to civilians and not necessarily improved policing. Although Chicago police had fewer complaints filed against them post training, there were still more than 67,000 instances of serious uses of force in 2014-2016, when the majority of officers had completed the training, and more than $90 \%$ of those uses were against people of color (Fan 2018).2

We urge scholars to consider whether and how procedural justice and other reforms affect that broader vision of democratic inclusion, including how police officers view their work and how their views shape the potential success for reforms (Carlson 2020, Sierra-Arévalo 2019, 2021). As Bell (2019, p. 201) writes, "because of the individualist and direct interaction-focused framing applied even in that work [procedural justice], this body of research tends to imply that the core issues shaping trust in law enforcement relate to the respect shown in encounters, not the social meanings of law enforcement to particular social groups, or the deep structures that link up with those meanings." Reduced legal cynicism and/or an increased sense of police legitimacy may turn out to be a negative outcome itself, given studies showing that police injustices can foster activism and community involvement. Desiring inclusion in a highly policed society may be the result of a limited imagination concerning how the state should keep citizens safe and constrains our thinking of what society expects of policing as an institution. In fact, both abolitionist activists and police officers themselves bemoan the fact that police are asked to serve so many roles they are not trained to do: social worker, mental health professional, addiction expert, and educator among many. That stunted imagination is one of the most invidious impacts of slow violence on residents, researchers, and society (Ward 2015).

Resolving our stunted imagination of policing in the academy should also stimulate new research projects to remedy the under- and overpolicing of communities of color, as current policing practices limit police efficacy in responding to community violence while prioritizing invasive encounters for minor offenses and complaints. Both practices fuel frustration with police, yet research indicates that increasing police presence would reduce serious crime rates. That research suggests that society still has much more to do to create safety for all and police may be a part of that. At the same time, the continued slow violence of policing indicates that the best investment in safety for these communities is not necessarily - and almost certainly not onlymore policing (Sharkey et al. 2017, Sharkey 2018).

There is much work to be done on how to best provide safety to all, but the need for scholarship studying how policing practices contribute to slow violence committed by other institutions, in addition to direct harms, is among the most pressing. Given that police are a tasked by society with solving, controlling, or containing social problems, research should examine policing along with the underlying social problem while recognizing the variety of the demands police face (Vitale 2017). Although residents' requests may be stymied by historical precedent, police are generally reacting to demands for service while also being the target of local activism for change.

\footnotetext{
${ }^{2}$ Serious force was defined as an officer using a Taser or firearm, a civilian filing a complaint, and/or an officer injuring a civilian.
} 
That activism has spurred many local and state governments to make reforms- from new mental health response practices to new trainings or use-of-force policies - and evaluating their effectiveness as well as how reforms spread across agencies, how they change as they spread, and whether or not residents perceive police, their safety, and their relationship with local government differently after such reforms is also imperative.

The social scientific study of police has been largely bifurcated between research on how to police better and research on the extent and typology of harms stemming from policing. If scholarship focuses solely on the first, it will miss the proverbial forest of racial capitalism for the trees of specific reforms that promote more efficient resource usage in the control and containment of the population. If, however, criminology shifts focus solely to the second, it may lose its policy relevance at a time when that connection is of the utmost importance. Both policyoriented and more-critical scholarship are enhanced by the careful integration of empirical research with theoretical work that considers how police harms might be valuable to the state. As Neocleous (2000, p. 118) argues, "the ultimate truth of the police is that it deals in and dispenses violence in protection of the interests of the state." This is not a call to stop studying best practices but to expand the criminological imagination beyond existing institutions, official data sources, and reform proposals to best identify, understand, and mitigate the slow violence of contemporary policing practices.

\section{DISCLOSURE STATEMENT}

The authors are not aware of any affiliations, memberships, funding, or financial holdings that might be perceived as affecting the objectivity of this review.

\section{ACKNOWLEDGEMENTS}

We thank members of the Critical Policing Studies Working Group including Daniel Gascón, Analicia Mejia Mesinas, Sebastián Sclofsky, and Javier Wilenmann, and the editors and staff of the Annual Review of Criminology for their thoughtful feedback and assistance.

\section{LITERATURE CITED}

Alang S, McAlpine D, McCreedy E, Hardeman R. 2017. Police brutality and Black health: setting the agenda for public health scholars. Am. J. Public Health 107(5):662-65

Alexander JC, Eyerman R, Giesen B, Smelser NJ, Sztompka P. 2004. Cultural Trauma and Collective Identity. Oakland: Univ. Calif. Press

Alves JA. 2018. The Anti-Black City: Police Terror and Black Urban Life in Brazil. Minneapolis, MN: Univ. Minn. Press.

Am. Public Health Assoc. 2018. Addressing law enforcement violence as a public health issue. Policy 201811, Am. Public Health Assoc., Washington, DC. 
https://www.apha.org/policies-and-advocacy/public-health-policy-statements/policydatabase/2019/01/29/law-enforcement-violence

Anderson C. 2016. White Rage: The Unspoken Truth of Our Racial Divide. New York: Bloomsbury Publ.

Ang D. 2020. The effects of police violence on inner-city students. Q. J. Econ. 136(1):115-68

Armenta A. 2017. Protect, Serve, and Deport: The Rise of Policing as Immigration Enforcement. Oakland: Univ. Calif. Press

Ba B. 2016. How far are you willing to go against the police? Evaluating the effects of citizen affidavits in Chicago. http://dx.doi.org/10.2139/ssrn.2897063

Ba B, Grogger J. 2019. The introduction of Tasers and police use of firearms: evidence from the Chicago Police Department. AEA Pap. Proc. 109:157-60

Ba B, Knox D, Mummolo J, Rivera R. 2021. The role of officer race and gender in policecivilian interactions in Chicago. Science 371(6530):696-702

Bacher-Hicks A, de la Campa E. 2020. Social costs of proactive policing: the impact of NYC's stop and frisk program on educational attainment. https://drive.google.com/file/d/1sSxhfmDY3N1VAN5XwyRObE65tmAZzhTj/view

Beck B. 2020. Policing gentrification: stops and low-level arrests during demographic change and real estate reinvestment. City Community 19(1):245-72

Beck B, Goldstein A. 2018. Governing through police? Housing market reliance, welfare retrenchment, and police budgeting in an era of declining crime. Soc. Forces 96(3):1183210

Beckett K, Harris A. 2011. On cash and conviction: monetary sanctions as misguided policy. Criminol. Public Policy 10(3):505-7

Bell MC. 2019. The community in criminal justice: subordination, consumption, resistance, and transformation. Du Bois Rev. Soc. Sci. Res. Race 16(1):197-220

Bell MC. 2020a. Anti-segregation policing. NYU Law Rev. 95(3):650-765

Bell MC. 2020b. Located institutions: neighborhood frames, residential preferences, and the case of policing. Am. J. Sociol. 125(4):917-23

Bittner E. 1970. The functions of the police in modern society: a review of background factors, current practices, and possible role models. Cent. Stud. Crime Delinquency Rep. NCJ 147822, Natl. Inst. Ment. Health, Chevy Chase, MD. https://www.ojp.gov/pdffiles1/Digitization/147822NCJRS.pdf

Boyles AS. 2015. Race, Place, and Suburban Policing: Too Close for Comfort. Oakland: Univ. Calif. Press 
Branas CC, Kondo MC, Murphy SM, South EC, Polsky D, MacDonald JM. 2016. Urban blight remediation as a cost-beneficial solution to firearm violence. Am. J. Public Health 106(12):2158-64

Brayne S. 2014. Surveillance and system avoidance: criminal justice contact and institutional attachment. Am. Sociol. Rev. 79(3):367-91

Brayne S. 2020. Predict and Surveil: Data, Discretion, and the Future of Policing. New York: Oxford Univ. Press

Brunson RK. 2007. "Police don't like Black people": African-American young men's accumulated police experiences. Criminology 6(1):71-102

Buchanan L, Bui Q, Patel JK. 2020. Black Lives Matter may be the largest movement in U.S. history. New York Times, July 3. https://www.nytimes.com/interactive/2020/07/03/us/george-floyd-protests-crowdsize.html

Bui AL, Coates MM, Matthay EC. 2018. Years of life lost due to encounters with law enforcement in the USA, 2015-2016. J. Epidemiol. Community Health 72(8):715-18

Campeau H, Levi R, Foglesong T. 2020. Policing, recognition, and the bind of legal cynicism. Soc. Probl. https://doi.org/10.1093/socpro/spaa017

Carlson J. 2020. Policing the Second Amendment: Guns, Law Enforcement, and the Politics of Race. Princeton, NJ: Princeton Univ. Press

Chalfin A, Kaplan J. 2020. How many complaints against police officers can be abated by incapacitating a few 'bad apples?' Criminol. Public Policy 20(2):351-70

Chalfin A, McCrary J. 2018. Are US cities underpoliced? Theory and evidence. Rev. Econ. Stat. 100(1):167-86

Cheng T. 2020. Input without influence: the silence and scripts of police and community relations. Soc. Probl. 67(1):171-89

Cobbina JE, Chaudhuri S, Rios VM, Conteh M. 2019. "I will be out there every day strong!" protest policing and future activism among Ferguson and Baltimore protesters. Soc. Forum 34(2):409-33

Cook P, Kapustin M, Ludwig J, Miller D. 2017. The effects of COPS office funding on sworn force levels, crime, and arrest: evidence from a regression discontinuity design. Off. COPS, Tech. Rep., US Dep Just., Washington, DC. https://cops.usdoj.gov/RIC/Publications/cops-w0827-pub.pdf

DeVylder JE, Oh HY, Nam B, Sharpe TL, Lehmann M, Link BG. 2017. Prevalence, demographic variation and psychological correlates of exposure to police victimisation in four US cities. Epidemiol. Psychiatr. Sci. 26(5):466-77 
The Slow Violence of Contemporary Policing (Forthcoming in Annual Review of Criminology)

By Rory Kramer and Brianna Remster

Dewan S, Kovaleski SF. 2020. Thousands of complaints do little to change police ways. New York Times, May 31, p. A1

Dow DM. 2019. Mothering While Black: Boundaries and Burdens of Middle-Class Parenthood. Oakland: Univ. Calif. Press

Eberhardt JL, Goff PA, Purdie VJ, Davies PG. 2004. Seeing Black: race, crime, and visual processing. J. Pers. Soc. Psychol. 87(6):876-93

Edwards F, Lee H, Esposito M. 2019. Risk of being killed by police use of force in the United States by age, race-ethnicity, and sex. PNAS 116(34):16793-98

Epp CR, Maynard-Moody S, Haider-Markel DP. 2014. Pulled Over: How Police Stops Define Race and Citizenship. Chicago: Univ. Chicago Press

Faber JW, Kalbfeld JR. 2019. Complaining while Black: racial disparities in the adjudication of complaints against the police. City Community 18(3):1028-67

Fan A. 2018. Chicago police are 14 times more likely to use force against young Black men than against Whites. The Intercept. https://theintercept.com/2018/08/16/chicago-policemisconduct-racial-disparity/

Fassin D. 2013. Enforcing Order: An Ethnography of Urban Policing. Malden, MA: Polity Press

Ferguson AG. 2019. The Rise of Big Data Policing: Surveillance, Race, and the Future of Law Enforcement. New York: NYU Press

Fernandes AD, Cadigan M, Edwards F, Harris A. 2019. Monetary sanctions: a review of revenue generation, legal challenges, and reform. Annu. Rev. Law Soc. Sci. 15:397-413

Fischer AG. 2019. "The place is gone!": policing Black women to redevelop downtown Boston. J. Soc. Hist. 53(1):7-26

Floyd v. City of New York, No. 8 Civ. 1034 (S.D.N.Y. 2013)

Forman J Jr. 2017. Locking Up Our Own: Crime and Punishment in Black America. New York: Farrar Straus Giroux

Garland D. 2001. The Culture of Control: Crime and Social Order in Contemporary Society. Chicago: Univ. Chicago Press

Gascón LD, Roussell A. 2019. The Limits of Community Policing: Civilian Power and Police Accountability in Black and Brown Los Angeles. New York: NYU Press

Geller A, Fagan J. 2019. Police contact and the legal socialization of urban teens. Russell Sage Found. J. Soc. Sci. 5(1):26-49

Geller A, Fagan J, Tyler T, Link BG. 2014. Aggressive policing and the mental health of young urban men. Am. J. Public Health 104(12):2321-27 
Geller A, Goff PA, Lloyd T, Haviland A, Obermark D, Glaser J. 2020. Measuring racial disparities in police use of force: methods matter. J. Quant. Criminol. https://doi.org/10.1007/s10940-020-09471-9

Gelman A, Fagan J, Kiss A. 2007. An analysis of the New York City Police Department's "stopand-frisk" policy in the context of claims of racial bias. J. Am. Stat. Assoc. 102(479):81323

Gilmore RW. 2007. Golden Gulag: Prisons, Surplus, Crisis, and Opposition in Globalizing California. Oakland: Univ. Calif. Press

Goel S, Rao JM, Shroff R. 2016. Precinct or prejudice? Understanding racial disparities in New York City’s stop-and-frisk policy. Ann. Appl. Stat. 10(1):365-94

Goff PA. 2021. Asking the right questions about race and policing. Science 371(6530):677-78

Goff PA, Jackson MC, Di Leone BAL, Culotta CM, DiTomasso NA. 2014. The essence of innocence: consequences of dehumanizing Black children. J. Pers. Soc. Psychol. 106(4):526-45

Goff PA, Rau H. 2020. Predicting bad policing: theorizing burdensome and racially disparate policing through the lenses of social psychology and routine activities. Ann. Am. Acad. Political Soc. Sci. 687(1):67-88

Goncalves F, Mello S. 2021. A few bad apples? Racial bias in policing. Am. Econ. Rev. 111(5):1406-41

González YM. 2017. "What citizens can see of the state": police and the construction of democratic citizenship in Latin America. Theor. Criminol. 21(4):494-511

Gonzalez SM. 2019. Making it home: an intersectional analysis of the police talk. Gend. Soc. 33(3):363-86

Gordon D. 2020. The police as place-consolidators: the organizational amplification of urban inequality. Law Soc. Inq. 45(1):1-27

Gottfredson DC, Crosse S, Tang Z, Bauer EL, Harmon MA, et al. 2020. Effects of school resource officers on school crime and responses to school crime. Criminol. Public Policy 19(3):905-40

Gottlieb A, Wilson R. 2019. The effect of direct and vicarious police contact on the educational achievement of urban teens. Children Youth Serv. Rev. 103:190-99

Hannon L, Neal M, Gustafson AR. 2021. Out-of-place and in-place policing: an examination of traffic stops in racially segregated Philadelphia. Crime Delinquency 67(6-7):868-90

Harcourt BE. 2001. Illusion of Order: The False Promise of Broken Windows Policing. Cambridge, MA: Harvard Univ. Press 
Harrell E, Davis E. 2020. Contacts between police and the public, 2018. Bur. Justice Stat. Rep. NCJ 255730, US Dep. Justice, Washington, DC. https://bjs.ojp.gov/content/pub/pdf/cbpp18st.pdf

Harris A. 2016. A Pound of Flesh: Monetary Sanctions as Punishment for the Poor. New York: Russell Sage Found.

Headley AM, D'Alessio SJ, Stolzenberg L. 2020. The effect of a complainant's race and ethnicity on dispositional outcome in police misconduct cases in Chicago. Race Justice 10(1):43-61

Herbert SK. 1997. Policing Space: Territoriality and the Los Angeles Police Department. Minneapolis, MN: Univ. Minn. Press

Herring C. 2019. Complaint-oriented policing: regulating homelessness in public space. Am. Sociol. Rev. 84(5):769-800

Hinton E, Cook D. 2021. The mass criminalization of Black Americans: a historical overview. Annu. Rev. Criminol. 4:261-86

Hoekstra M, Sloan C. 2020. Does race matter for police use of force? Evidence from 911 calls. NBER Work Pap. 26774. https://www.nber.org/papers/w26774

Kaba M. 2020. Yes, we mean literally abolish the police. New York Times, June 14, p. SR2

Kaplan J, Chalfin A. 2019. More cops, fewer prisoners? Criminol. Public Policy 18(1):171-200

Knox D, Lowe W, Mummolo J. 2020. Administrative records mask racially biased policing. Am. Political Sci. Rev. 114(3):619-37

Koch I. 2017. Moving beyond punitivism: punishment, state failure and democracy at the margins. Punishm. Soc. 19(2):203-20

Kramer R. 2017. Defensible spaces in Philadelphia: exploring neighborhood boundaries through spatial analysis. Russell Sage Found. J. Soc. Sci. 3(2):81-101

Kramer R, Remster B. 2018. Stop, frisk, and assault? Racial disparities in police use of force during investigatory stops. Law Soc. Rev. 52(4):960-93

Kramer R, Remster B, Charles CZ. 2017. Black lives and police tactics matter. Contexts 16(3):20-25

Krieger N. 2015. Police killings, political impunity, racism and the people's health. Harv. Public Health Rev. 3:1-3

Lara-Millán A. 2014. Public emergency room overcrowding in the era of mass imprisonment. Am. Sociol. Rev. 79(5):866-87 
Lautenschlager R, Omori M. 2019. Racial threat, social (dis)organization, and the ecology of police: towards a macro-level understanding of police use-of-force in communities of color. Justice Q. 36(6):1050-71

Legewie J. 2016. Racial profiling and use of force in police stops: how local events trigger periods of increased discrimination. Am. J. Sociol. 122(2):379-424

Legewie J, Fagan J. 2016. Group threat, police officer diversity and the deadly use of police force.

https://scholarship.law.columbia.edu/cgi/viewcontent.cgi?article=2981\& context=faculty_ scholarship

Legewie J, Fagan J. 2019. Aggressive policing and the educational performance of minority youth. Am. Sociol. Rev. 84(2):220-47

Lerman AE, Weaver VM. 2014. Arresting Citizenship: The Democratic Consequences of American Crime Control. Chicago: Univ. Chicago Press

Levchak PJ. 2017. Do precinct characteristics influence stop-and-frisk in New York City? A multi-level analysis of post-stop outcomes. Justice Q. 34(3):377-406

Levine JR. 2017. The paradox of community power: cultural processes and elite authority in participatory governance. Soc. Forces 95(3):1155-79

Lum C, Koper CS, Wilson DB, Stoltz M, Goodier M, et al. 2020. Body-worn cameras' effects on police officers and citizen behavior: a systematic review. Campbell Syst. Rev.

16(3):e1112

Lum C, Stoltz M, Koper CS, Scherer JA. 2019. Research on body-worn cameras: what we know, what we need to know. Criminol. Public Policy 18(1):93-118

McCarthy B, Hagan J, Herda D. 2020. Neighborhood climates of legal cynicism and complaints about abuse of police power. Criminology 58(3):510-36

McKee JB. 1993. Sociology and the Race Problem: The Failure of a Perspective. Chicago: Univ. Illinois Press

McMillen D, Sarmiento-Barbieri I, Singh R. 2019. Do more eyes on the street reduce crime? Evidence from Chicago's safe passage program. J. Urban Econ. 110:1-25

Meares TL, Tyler TR, Gardener J. 2015. Lawful or fair? How cops and laypeople perceive good policing. J. Crim. Law Criminol. 105(2):297-344

Mello S. 2019. More COPS, less crime. J. Public Econ. 172:174-200

Modestino AS. 2019. How do summer youth employment programs improve criminal justice outcomes, and for whom? J. Policy Anal. Manag. 38(3):600-28 
The Slow Violence of Contemporary Policing (Forthcoming in Annual Review of Criminology)

By Rory Kramer and Brianna Remster

Morrow WJ, White MD, Fradella HF. 2017. After the stop: exploring the racial/ethnic disparities in police use of force during Terry stops. Police Q. 20(4):367-96

Muhammad KG. 2010. The Condemnation of Blackness: Race, Crime, and the Making of Modern Urban America. Cambridge, MA: Harvard Univ. Press

Muñiz A. 2015. Police, Power, and the Production of Racial Boundaries. New Brunswick, NJ: Rutgers Univ. Press

Nagin DS, Telep CW. 2017. Procedural justice and legal compliance. Annu. Rev. Law Soc. Sci. $13: 5-28$

Nagin DS, Telep CW. 2020. Procedural justice and legal compliance: a revisionist perspective. Criminol. Public Policy 19(3):761-86

Natl. Acad. Sci. Eng. Med. 2018. Proactive Policing: Effects on Crime and Communities. Washington, DC: Natl. Acad. Press

Neil R, Winship C. 2018. Methodological challenges and opportunities in testing for racial discrimination in policing. Annu. Rev. Criminol. 2:73-98

Neocleous M. 2000. The Fabrication of Social Order: A Critical Theory of Police Power. London: Pluto Press

Nixon R. 2011. Slow Violence and the Environmentalism of the Poor. Cambridge, MA: Harvard Univ. Press

Onwuachi-Willig A. 2016. The trauma of the routine: lessons on cultural trauma from the Emmett Till verdict. Sociol. Theory 34(4):335-57

Ouellet M, Hashimi S, Gravel J, Papachristos AV. 2019. Network exposure and excessive use of force: investigating the social transmission of police misconduct. Criminol. Public Policy 18(3):675-704

Owens EG. 2017. Testing the school-to-prison pipeline. J. Policy Anal. Manag. 36(1):11-37

Owens E, Mioduszewski M, Bates C. 2021. How valuable are civil liberties? Evidence from gang injunctions, crime, and housing prices in Southern California. https://cpb-use2.wpmucdn.com/faculty.sites.uci.edu/dist/9/540/files/2021/01/CGI-Jan-2021-1.pdf

Owusu-Bempah A. 2017. Race and policing in historical context: dehumanization and the policing of Black people in the 21st century. Theor. Criminol. 21(1):23-34

Peyton K, Sierra-Arévalo M, Rand DG. 2019. A field experiment on community policing and police legitimacy. PNAS 116(40):19894-98

Powell AJ, Phelps M. 2019. "It's like we don't exist": an intersectional analysis of women's legal estrangement. Paper presented at the $114^{\text {th }}$ Annual Meeting of the American Sociological Association, New York, NY 
Pres. Task Force 21st Century Polic. 2015. Final report of the President's task force on 21st century policing. Off. COPS Rep., US Dep. Justice, Washington, DC. https://cops.usdoj.gov/pdf/taskforce/taskforce_finalreport.pdf

Prowse G, Weaver VM, Meares TL. 2020. The state from below: distorted responsiveness in policed communities. Urban Aff. Rev. 56(5):1423-71

Pulido L. 2017. Geographies of race and ethnicity II: environmental racism, racial capitalism and state-sanctioned violence. Prog. Hum. Geog. 41(4):524-33

Quispe-Torreblanca EG, Stewart N. 2019. Causal peer effects in police misconduct. Nat. Hum. Behav. 3(8):797-807

Ray R. 2017. Black people don't exercise in my neighborhood: perceived racial composition and leisure-time physical activity among middle class Blacks and Whites. Soc. Sci. Res. $66: 42-57$

Ray V. 2019. A theory of racialized organizations. Am. Sociol. Rev. 84(1):26-53

Remster B, Kramer R. 2018. Race, space, and surveillance: understanding the relationship between criminal justice contact and institutional involvement. Socius 4:1-16

Remster B, Smith C, Kramer R. 2019. Say her name: gender, race, and police violence in the shadow of controlling images. Paper presented at the $114^{\text {th }}$ Annual Meeting of the American Sociological Association, New York, NY

Rios VM. 2011. Punished: Policing the Lives of Black and Latino Boys. New York: NYU Press

Rios VM, Prieto G, Ibarra JM. 2020. Mano suave-mano dura: legitimacy policing and Latino stop-and-frisk. Am. Sociol. Rev. 85(1):58-75

Rios VM, Vigil JD. 2017. Human Targets: Schools, Police, and the Criminalization of Latino Youth. Chicago: Univ. Chicago Press

Ritchie AJ. 2017. Invisible No More: Police Violence Against Black Women and Women of Color. Boston: Beacon Press

Roussell A. 2015. Policing the anticommunity: race, deterritorialization, and labor market reorganization in south Los Angeles. Law Soc. Rev. 49(4):813-45

Roussell A, Henne K, Glover KS, Willits D. 2017. Impossibility of a "reverse racism” effect. Criminol. Public Policy 18(1):E5-16

Roussell A, Gascón LD. 2014. Defining "policeability”: cooperation, control, and resistance in South Los Angeles community-police meetings. Soc. Probl. 61(2):237-58

Rozema K, Schanzenbach M. 2019. Good cop, bad cop: using civilian allegations to predict police misconduct. Am. Econ. J. Econ. Policy 11(2):225-68

Russell-Brown K. 2009. The Color of Crime, Vol. 45. New York: NYU Press 
Samara TR. 2010. Order and security in the city: producing race and policing neoliberal spaces in South Africa. Ethn. Racial Stud. 33(4):637-55

Sclofsky S. 2020. "Our North is the South": lessons from police-community encounters in São Paulo and Los Angeles. In The Routledge Handbook of Public Criminologies, ed. K Henne, R Shah, pp 202-12. New York: Routledge

Seim J. 2020. Bandage, Sort, and Hustle: Ambulance Crews on the Front Lines of Urban Suffering. Oakland: Univ. Calif. Press

Seri G. 2012. Seguridad: Crime, Police Power, and Democracy in Argentina. New York: Continuum

Sewell AA. 2017. The illness associations of police violence: differential relationships by ethnoracial composition. Sociol. Forum. 32:975-97

Sewell AA, Jefferson KA. 2016. Collateral damage: the health effects of invasive police encounters in New York City. J. Urban Health 93(1):42-67

Sewell AA, Jefferson KA, Lee H. 2016. Living under surveillance: gender, psychological distress, and stop-question-and-frisk policing in New York City. Soc. Sci. Med. 159:1-13

Shannon SKS, Uggen C, Schnittker J, Thompson M, Wakefield S, Massoglia M. 2017. The growth, scope, and spatial distribution of people with felony records in the United States, 1948-2010. Demography 54:1795-818

Sharkey P. 2018. Uneasy Peace: The Great Crime Decline, the Renewal of City Life, and the Next War on Violence. New York: Norton

Sharkey P, Torrats-Espinosa G, Takyar D. 2017. Community and the crime decline: the causal effect of local nonprofits on violent crime. Am. Sociol. Rev. 82(6):1214-40

Sharkey P, Schwartz AE, Ellen IG, Lacoe J. 2014. High stakes in the classroom, high stakes on the street: the effects of community violence on student's standardized test performance. Sociol. Sci. 1:199-220

Shedd C. 2015. Unequal City: Race, Schools, and Perceptions of Injustice. New York: Russell Sage Found.

Sierra-Arévalo M. 2019. Technological innovation and police officers' understanding and use of force. Law Soc. Rev. 53(2):420-51

Sierra-Arévalo M. 2021. American policing and the danger imperative. Law Soc. Rev. 55(1):70103

Simon J. 2009. Governing through Crime: How the War on Crime Transformed American Democracy and Created a Culture of Fear. New York: Oxford Univ. Press 
Slocum LA, Wiley SA. 2018. Experience of the expected? Race and ethnicity differences in the effects of police contact on youth. Criminology 56(2):402-32

Smith BW, Holmes MD. 2014. Police use of excessive force in minority communities: a test of the minority threat, place, and community accountability hypotheses. Soc. Probl. 61(1):83-104

Smith Lee JR, Robinson MA. 2019. "That's my number one fear in life. It's the police": examining young Black men's exposures to trauma and loss resulting from police violence and police killings. J. Black Psychol. 45(3):143-84

Smith NA, Voisin DR, Yang JP, Tung EL. 2019. Keeping your guard up: hypervigilance among urban residents affected by community and police violence. Health Aff. 38(10):1662-69

Smith MR, Tillyer R, Lloyd C, Petrocelli M. 2021. Benchmarking disparities in police stops: a comparative application of 2nd and 3rd generation techniques. Justice Q. 38(3):513-36

Sorensen L, Shen Y, Bushway SD. 2020. Making schools safer and/or escalating disciplinary response: a study of police officers in North Carolina schools. http://dx.doi.org/10.2139/ssrn.3577645

Soss J, Weaver V. 2017. Police are our government: politics, political science, and the policing of race-class subjugated communities. Annu. Rev. Political Sci. 20:565-91

Stuart F. 2011. Race, space, and the regulation of surplus labor: policing African Americans in Los Angeles's skid row. Souls 13(2):197-212

Stuart F, Benezra A. 2018. Criminalized masculinities: how policing shapes the construction of gender and sexuality in poor Black communities. Soc. Probl. 65(2):174-90

Sutherland E, Cressey D. 1955. Principles of Criminology. Chicago: J.B. Lippincott

Taniguchi TA, Hendrix JA, Levin-Rector A, Aagaard BP, Strom KJ, Zimmer SA. 2017. Extending the veil of darkness approach: an examination of racial disproportionality in traffic stops in Durham, NC. Police Q. 20(4):420-48

Tomaskovic-Devey D, Mason M, Zingraff M. 2004. Looking for the driving while Black phenomena: conceptualizing racial bias processes and their associated distributions. Police Q. 7(1):3-29

Trinkner R, Kerrison EM, Goff PA. 2019. The force of fear: police stereotype threat, selflegitimacy, and support for excessive force. Law Hum. Behav. 43(5):421-35

Tyler TR. 2003. Procedural justice, legitimacy, and the effective rule of law. Crime Justice 30:283-357

Tyler TR. 2004. Enhancing police legitimacy. Ann. Am. Acad. Political Soc. Sci. 593(1):84-99 
Wacquant L. 2009. Punishing the Poor: The Neoliberal Government of Social Insecurity. Durham, NC: Duke Univ. Press

Ward G. 2015. The slow violence of state organized race crime. Theor. Criminol. 19(3):299-314

Warren P, Tomaskovic-Devey D, Smith W, Zingraff M, Mason M. 2006. Driving while Black: bias processes and racial disparity in police stops. Criminology 44(3):709-38

Weaver V, Prowse G, Piston S. 2019. Too much knowledge, too little power: an assessment of political knowledge in highly policed communities. J. Politics 81(3):1153-66

Weisburst EK. 2019a. Patrolling public schools: the impact of funding for school police on student discipline and long-term education outcomes. J. Policy Anal. Manag. 38(2):33865

Weisburst EK. 2019b. Safety in police numbers: evidence of police effectiveness from federal COPS grant applications. Am. Law Econ. Rev. 21(1):81-109

Welsh M, Chanin J, Henry S. 2021. Complex colorblindness in police processes and practices. Soc. Probl. 68(2):374-92

Wood G, Roithmayr D, Papachristos AV. 2019. The network structure of police misconduct. Socius 5:1-18

Wood G, Tyler TR, Papachristos AV, Roth, J, Sant'Anna, PHC. 2021. Correction for Wood et al., procedural justice training reduces police use of force and complaints against officers. $P N A S$ https://doi.org/10.31235/osf.io/xf32m

Vitale AS. 2017. The End of Policing. Brooklyn, NY: Verso Books

Wrigley-Field E. 2020. Life years lost to police encounters in the United States. Socius 6:1-3

Zhao L, Papachristos AV. 2020. Network position and police who shoot. Ann. Am. Acad. Political Soc. Sci. 687(1):89-112 